\title{
Disproving claims for small-bodied humans in the Palauan archipelago
}

Jessica H. Stone ${ }^{1, *}$, Scott M. Fitzpatrick ${ }^{1,2} \&$ Matthew F. Napolitano ${ }^{1}$

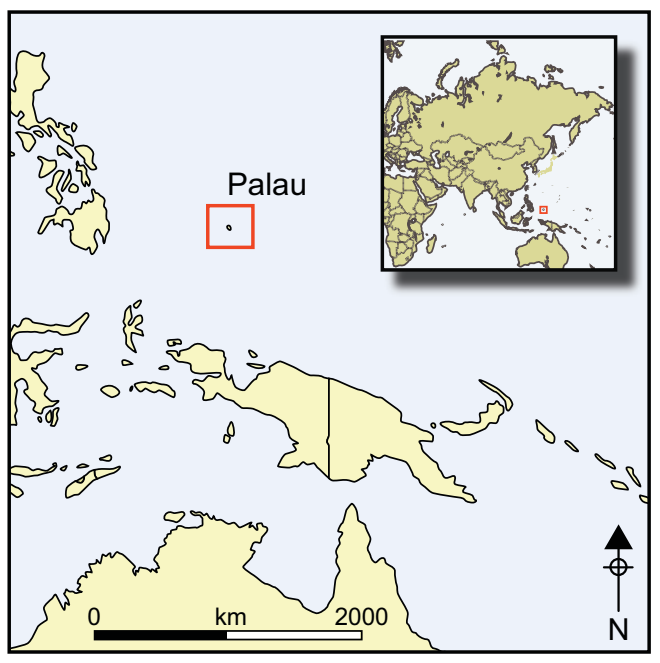

Recent excavation at Ucheliungs Cave in Palau has provided new evidence in the debate concerning the colonisation of the Palauan archipelago. An abundance of faunal material and the presence of transported artefacts contradict a previous interpretation that the site represents an early burial cave containing purported small-bodied humans. New radiocarbon dates suggest long-term use of the cave for both mortuary activity and small-scale marine foraging that may slightly precede the accepted date for the earliest human occupation of Palau. The results of this research here discount earlier claims for insular dwarfism among the earliest inhabitants of these islands.

Keywords: Micronesia, Palau, Ucheliungs Cave, radiocarbon dating, insular dwarfism

\section{Introduction}

The use of caves and rockshelters for disposing of the dead is the oldest form of mortuary behaviour in the Palauan archipelago of western Micronesia (Fitzpatrick \& Nelson 2008). Numerous sites throughout the hundreds of limestone Rock Islands have been identified as locations where human skeletal remains were buried or deposited, beginning as early as $c .1000 \mathrm{cal}$ BC. Two cave sites in particular, Omedokel and Ucheliungs, have received considerable attention. Researchers had previously interpreted human skeletal fragments found at these sites as representing 'small-bodied' individuals, arguing that the remains "exhibit a number of characteristics normally associated with more primitive species of the genus Homo" and "exemplify the regularity with which small body size—physiological dwarfing-emerges in island contexts" (Berger et al. 2008: 9). Those researchers also suggested that the Rock Islands provided an environment that was conducive to insular dwarfism, where, over the course of a few generations, an isolated population developed a

\footnotetext{
Department of Anthropology, University of Oregon, Eugene, OR 97403, USA

2 Museum of Natural and Cultural History, University of Oregon, 1680 E. $15^{\text {th }}$ Avenue, Eugene, OR 97403, USA

*Author for correspondence (Email: jstone3@uoregon.edu)
} 
series of unique morphological characteristics, including small body size. Fitzpatrick et al. (2008) disputed these results, noting a number of inconsistencies and erroneous statements regarding the potential of Palau's environment to induce these types of biological changes. Unfortunately, there has been no subsequent field research at these sites to clarify and examine these and a number of other unresolved issues.

Here, we report on additional fieldwork undertaken in 2015 at the Ucheliungs site (site number: B:OR-14:8), including surface examination and excavation of a $1 \times 1 \mathrm{~m}$ unit adjacent to one excavated by Berger $e t$ al. (2008). The primary goal was not necessarily to compile a comparative human skeletal sample from the site, as the collection from the nearby early mortuary site of Chelechol ra Orrak (see Figure 1) is extensive, including more than 45 individuals (Nelson et al. 2015). Instead, we aimed to provide additional stratigraphic data, cultural remains and radiocarbon dates, which we deemed especially critical, given that Berger et al. (2008: 2) described the cave as "not contain[ing] associated faunal remains, and cultural artefacts are rare". Our results indicate the contrary, as we discovered thousands of faunal specimens and an assemblage of artefacts, including pottery and a bone implement. Four new radiocarbon assays on marine shell provide additional early settlement dates for Palau. This is supported by the presence of volcanic, sandtempered pottery that has also been recovered from contemporaneous sites in the Rock Islands. Both lines of evidence hint at long-term use of the site that seems to both precede and come after the deposition of human remains, and refute the research and interpretations of Berger et al. (2008).

\section{Background}

\section{Environmental}

The Palauan archipelago, located in the Western Caroline Islands of Micronesia, comprises hundreds of islands of great geological diversity (Figure 1). These include the hundreds of small uplifted coral limestone 'Rock Islands' in the central and southern portions of the archipelago. These are generally small with low elevation and display jagged karst topography, rockshelters and caves (Corwin et al. 1956). Ucheliungs is a burial cave located in the northern Rock Islands, south-west of Babeldaob and east of Koror, and is known locally as 'Tarzan Cave' due to the vines that extend through the roof to the cavern floor. The close proximity of the cave to the main city of Koror, along with its natural and known cultural features, has made it a popular attraction for kayakers and other visitors.

\section{Archaeological}

Archaeological evidence from two sites in the Rock Islands, Chelechol ra Orrak and Ulong Island, supports the probable colonisation of Palau dating to $c$. 1350-1050 cal BC (Athens $\&$ Ward 1999; Fitzpatrick 2003a; Clark 2004). The former site is associated with human burials, the latter with ceramics, shellfish and stone abraders, and flakes (Fitzpatrick 2002, 2003a; Clark 2004; Clark et al. 2006; Ono \& Clark 2012). Later occupation (c. AD 1050-1350) of many of the southern Rock Islands is associated with villages constructed with elaborate stonework, including docks, house foundations and pathways. These are 


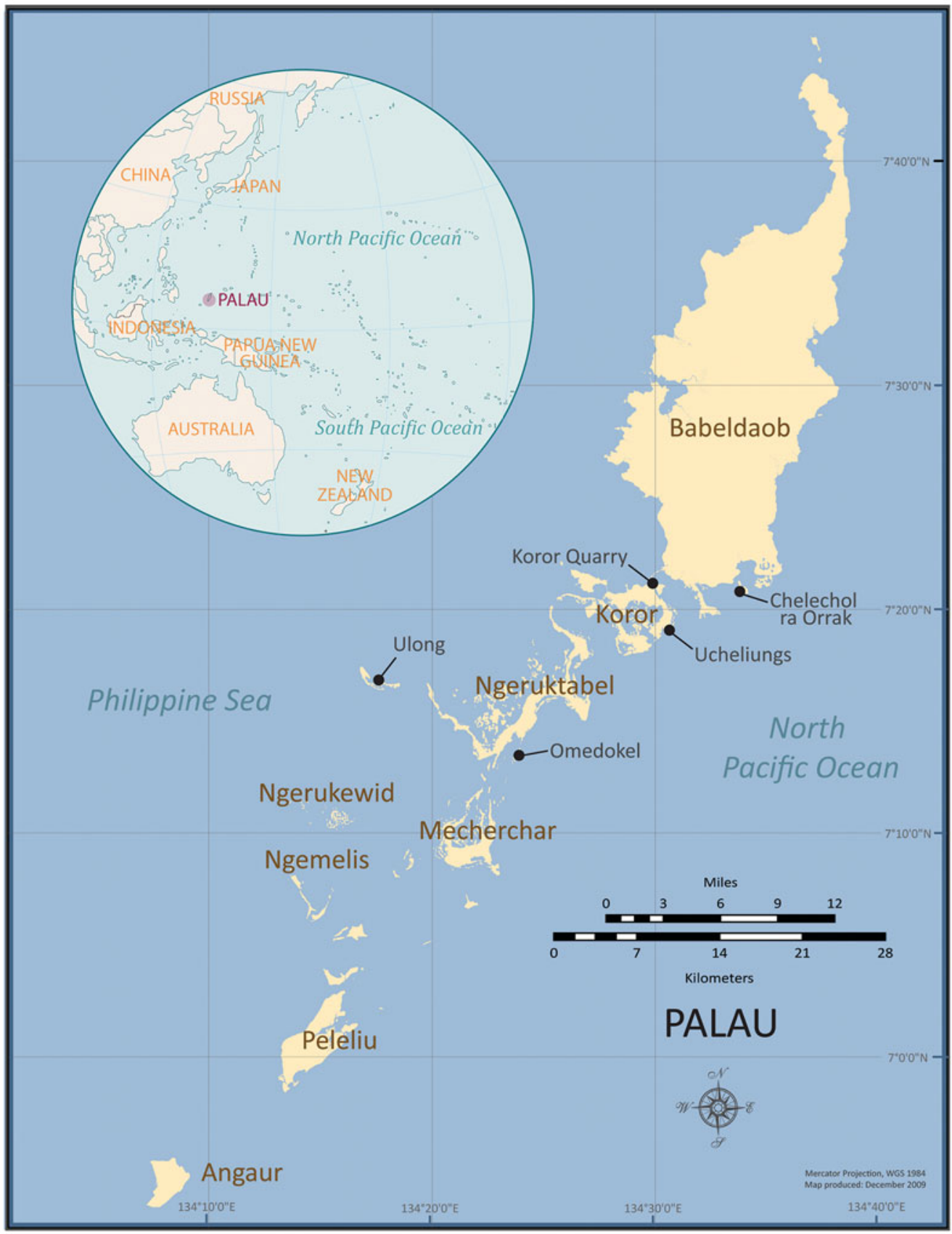

Figure 1. Map of Micronesia and Palau, showing the location of Ucheliungs Cave and other sites mentioned in the text.

(C) Antiquity Publications Ltd, 2017 


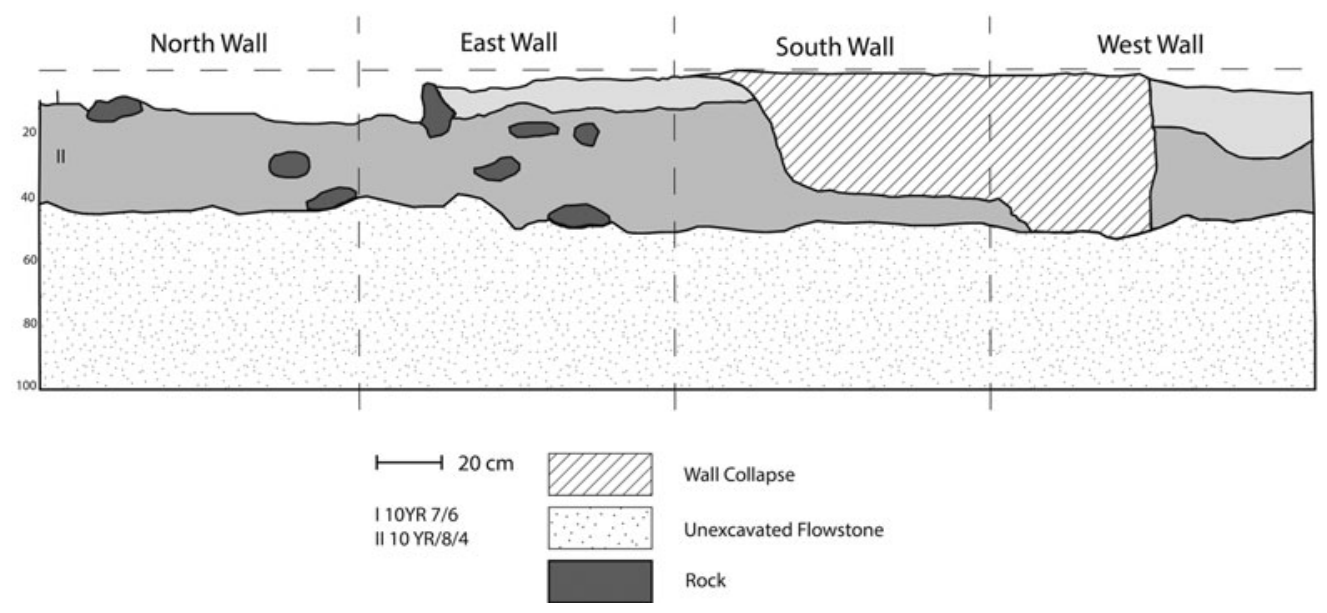

Figure 2. Stratigraphic profile of test unit 2.

contemporaneous with, or slightly later than, coastal stonework village sites found on the larger islands of Babeldaob and Koror (Masse et al. 2006; Clark \& Reepmeyer 2012).

Ucheliungs Cave was first excavated by Berger and colleagues in 2006. They conducted surface collection of human remains from the cave interior and excavated a $1 \times 1 \mathrm{~m}$ test unit (hereafter referred to as test unit 1, or TU1), that together yielded more than 1000 specimens of human bone (Berger et al. 2008). Results suggested that the area was used exclusively for mortuary practices and contained little, if any, associated faunal or cultural material, and that the site probably contained large additional quantities of human remains. Radiocarbon dates on human bone were reported as ranging from 940 BC-AD 530, while dates from Omedokel Cave suggested a slightly later and longer period of use (350 BC-AD 1010) (Berger et al. 2008). As Fitzpatrick et al. (2008) noted, Berger et al. (2008) calibrated their dates as terrestrial; yet given the probability of a major marine dietary component for the human inhabitants, the recalibration of these dates with a mixed (50/50) diet pushes them to hundreds of years later.

\section{Methods}

TU1 was placed in the western portion of the cave, which appeared not to have been backfilled following excavation. The unit's location was compared to the site map published in Berger et al. (2008) to verify its position. A $1 \times 1 \mathrm{~m}$ test unit (test unit 2; TU2) was placed east of and directly adjacent to TU1. TU2 was excavated by trowel in arbitrary $0.1 \mathrm{~m}$ levels (spits) from the ground's surface to a depth of approximately $0.5 \mathrm{~m}$, at which point a layer of dense flowstone was encountered. Arbitrary levels were chosen based on Berger et al.'s (2008) observation that the first $0.5 \mathrm{~m}$ of sediment comprised a single stratigraphic layer. As excavation proceeded, this was found not to be the case. Our $0.1 \mathrm{~m}$ levels closely followed a stratigraphic change observed at a depth of approximately $0.1 \mathrm{~m}$ (Figure 2). Soil in the first $0.1 \mathrm{~m}$ (layer I) was a fine-grained, pale brown sand (Munsell description code: 10YR 7/6). 


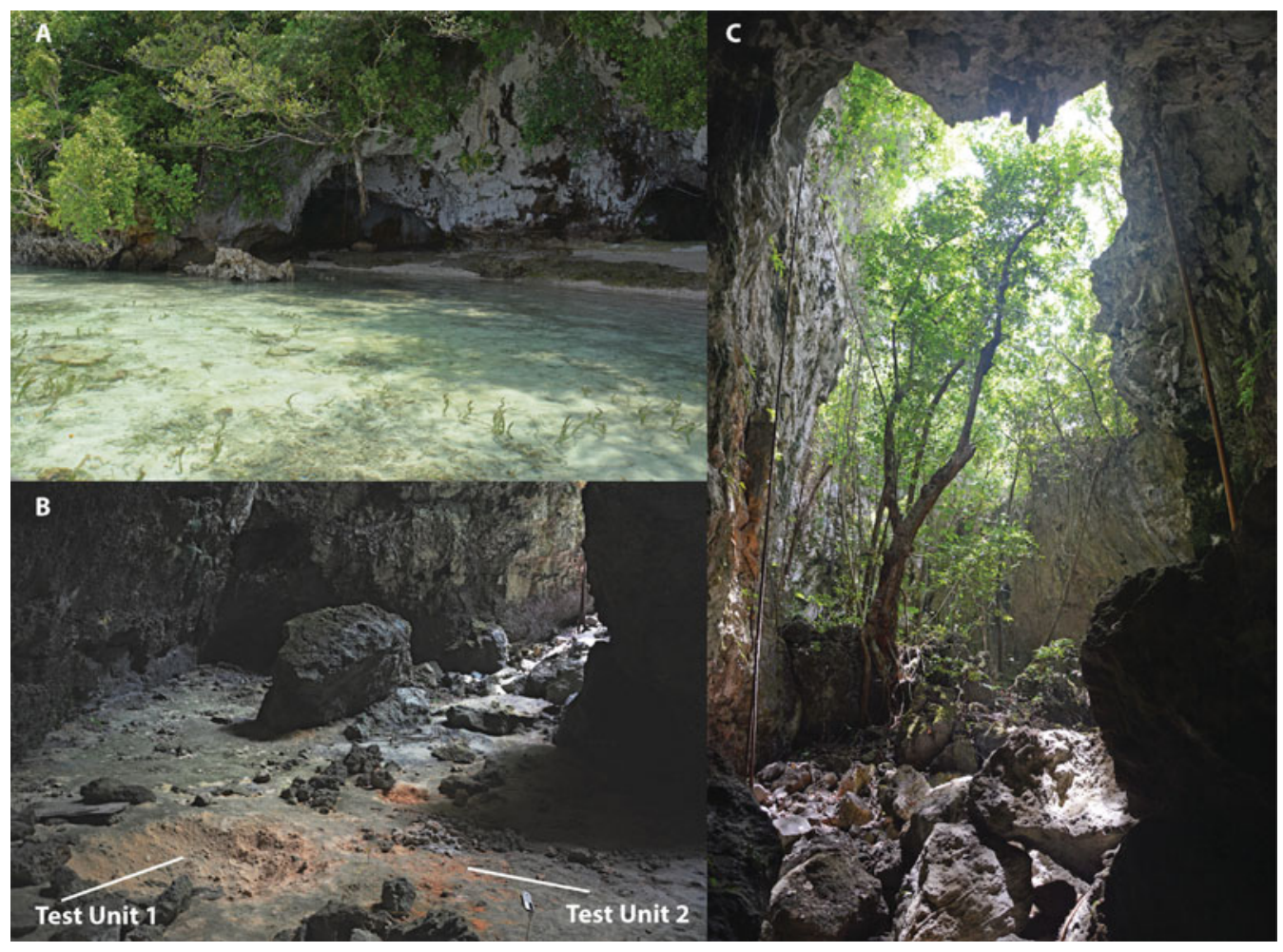

Figure 3. A) The entrance to Ucheliungs Cave; B) facing north inside Ucheliungs Cave. Test unit 1 is to the left, and the location of test unit 2 is outlined to the right; $C$ ) interior of Ucheliungs Cave, facing east and showing the cave roofs collapse.

From approximately $0.1-0.2 \mathrm{~m}$, patches of finer, loosely packed yellowish sand (Munsell description code: 10YR 8/4) were encountered. This then formed a second stratigraphic layer (layer II) by $0.2 \mathrm{~m}$ that was situated above the flowstone deposit (Figure 3).

All soil was dry-screened through a $3.175 \mathrm{~mm}$ mesh. Human skeletal material and artefacts were collected when encountered in surface contexts. All cultural material, including faunal remains, artefacts, charcoal and human skeletal fragments were collected, sorted into basic categories and entered into the ArcheoLINK database management software that uses a barcode label system to link all material and results of subsequent analyses to the original provenience. Further sorting and analysis was undertaken at the University of Oregon Island and Coastal Archaeology Laboratory (ICAL).

Skeletal remains were identified by element, and when possible, sex and age were determined using standard osteological methods (Buikstra \& Ubelaker 1994; Scheuer et al. 2000). Pathology, trauma and anomalies were also recorded when present (Buikstra \& Ubelaker 1994; Scheuer et al. 2000). Faunal remains were sorted to the lowest possible taxonomic level and quantified using standard procedures including number of identified specimens (NISP), minimum number of individuals (MNI) and weight (g) (Reitz \& Wing 2008).

Pottery sherds were weighed and preliminarily analysed to identify temper, form and any surface treatments. A representative sample from each level (eight sherds in total) was (C) Antiquity Publications Ltd, 2017 
selected for thin-section analysis. A coarse analysis of temper constituents was conducted by Kathleen Marsaglia (Department of Geological Sciences, California State University, Northridge).

\section{Radiocarbon dates}

Seven samples of marine shell $(\mathrm{n}=4)$ and human bone $(\mathrm{n}=3)$ were submitted for radiocarbon dating. Marine shell samples were pretreated at ICAL with a 10 per cent hydrochloric acid ( $\mathrm{HCl}$ ) solution 'leach', dried and drilled to obtain a powdered sample. Although bone samples were sent to two different laboratories, neither was able to obtain sufficient collagen following pretreatment procedures. Dating of these specimens was, therefore, unsuccessful. This can probably be attributed to the mineralised nature of the human remains recovered, with results similar to those presented by Berger et al. (2008), who reported only six dates from their 25 samples selected for AMS dating. All dates, including those previously reported, were calibrated using $\mathrm{OxCal} v 4.2$ with a 50 per cent mixed marine/terrestrial curve for bone samples and the Marine13 curve for shell (Bronk Ramsey 2009; Reimer et al. 2013) (Table 1). Given the wide range of marine reservoir corrections $(\Delta \mathrm{R})$ available for Palau, ${ }^{14} \mathrm{C}$ dates from Ucheliungs Cave are presented with all $\Delta$ Rs for the archipelago (Table 2).

Marine shell is sometimes viewed as problematic for radiocarbon dating due to a variety of issues, including inbuilt age from both global and localised oceanic carbon reservoirs, the 'old shell' effect and the possibility that natural deposits are being dated and interpreted as cultural events (e.g. Rick et al. 2005). The marine shell excavated at Ucheliungs Cave, however, is unlikely to be naturally deposited, given the distance (approximately $20 \mathrm{~m}$ ) and upward slope from the cave entrance and beach to TU2, and due to a lack of shell observed on the cave floor during excavations; it is improbable that tidal activity or storm surges washed in beach material, or that marine shell reached the cave interior via other natural mechanisms. The new marine shell dates from Ucheliungs Cave-which were taken from larger specimens of taxa known to have been used for subsistence and found at other archaeological sites in the Rock Islands_-span 2110-760 cal BC (Table 1). The latter end of the date range overlaps with two of the human bone samples reported by Berger et al. (2008). The two marine shell dates from level 4 (D-AMS 016831, D-AMS 017433) calibrate to the earliest known acceptable range of Palauan colonisation and are generally coeval with those from Ulong and Chelechol ra Orrak. This provides further support to the presence of Palauans in the Rock Islands just prior to and after $1050 \mathrm{BC}$. The sample from the lowest level (D-AMS 017434), which calibrates to 2110-1900 BC, extends beyond the earliest acceptable archaeological dates in the archipelago. It is possible that the sample was subfossil shell, or was brought in as part of incidental debris; confirmation with additional dates is required. Regardless, the association of human bone with these dates implies that burial or other activities may have taken place at Ucheliungs Cave earlier than Berger et al. (2008) suggested. This revised chronology reduces the amount of time between the initial colonisation of Palau and use of the site, and does not allow adequate time for insular dwarfism to occur within the population following arrival in the archipelago. 
Table 1. Radiocarbon dates from Ucheliungs Cave, including recalibrated dates from Berger et al. (2008).

\begin{tabular}{|c|c|c|c|c|c|}
\hline $\begin{array}{l}\text { Laboratory/ } \\
\text { sample number }\end{array}$ & Sample type & Provenience & $\begin{array}{l}\text { Radiocarbon } \\
\text { age }\end{array}$ & $\begin{array}{l}{ }^{13} \mathrm{C} /{ }^{12} \mathrm{C} \\
\text { ratio }\end{array}$ & $\begin{array}{c}\text { Calibrated date } \\
(2 \text { sigma } \\
\text { BC/AD })\end{array}$ \\
\hline B:OR-14:8-1200 & Human bone & not reported & $2550 \pm 50$ & -15.1 & $720-370 \mathrm{BC}$ \\
\hline B:OR-14:8-1201 & Human bone & not reported & $2530 \pm 50$ & -15.3 & $720-350$ BC \\
\hline B:OR-14:8-1202 & Human bone & not reported & $2280 \pm 50$ & -15 & $350-1 \mathrm{BC}$ \\
\hline B:OR-14:8-1203 & Human bone & not reported & $2260 \pm 50$ & -14.7 & 340 BC-AD 20 \\
\hline B:OR-14:8-1204 & Human bone & not reported & $2190 \pm 50$ & -15.9 & $170 \mathrm{BC}-\mathrm{AD} 70$ \\
\hline B:OR-14:8-1205 & Human bone & not reported & $2400 \pm 40$ & -14.4 & $390-180$ BC \\
\hline B:OR-14:8-1206 & Human bone & not reported & $1520 \pm 40$ & -17 & AD 630-770 \\
\hline B:OR-14:8-1207 & Human bone & not reported & $1570 \pm 40$ & -14 & AD 570-700 \\
\hline D-AMS 017432 & $\begin{array}{l}\text { Marine shell } \\
\text { (Cypraea tigris) }\end{array}$ & $\begin{array}{l}\text { TU2, level } 3 \\
(0.2-0.3 \mathrm{~m} \\
\text { depth })\end{array}$ & $3000 \pm 30$ & not reported & $900-760 \mathrm{BC}$ \\
\hline D-AMS 016831 & $\begin{array}{l}\text { Marine shell } \\
\text { (bivalve, } \\
\text { probable } \\
\text { Cardiidae sp.) }\end{array}$ & $\begin{array}{l}\text { TU2, level } 4 \\
(0.3-0.4 \mathrm{~m} \\
\text { depth })\end{array}$ & $3450 \pm 30$ & -17.6 & $1460-1280 \mathrm{BC}$ \\
\hline D-AMS 017433 & $\begin{array}{l}\text { Marine shell } \\
\text { (Fimbria sp.) }\end{array}$ & $\begin{array}{l}\text { TU2, level } 4 \\
(0.3-0.4 \mathrm{~m} \\
\text { depth })\end{array}$ & $3370 \pm 30$ & not reported & $1380-1200 \mathrm{BC}$ \\
\hline D-AMS 017434 & $\begin{array}{l}\text { Marine shell } \\
\text { (bivalve, } \\
\text { probable } \\
\text { Cardiidae sp.) }\end{array}$ & $\begin{array}{l}\text { TU2, level } 5 \\
(0.4-0.5 \mathrm{~m} \\
\text { depth })\end{array}$ & $3960 \pm 30$ & not reported & 2110-1900 BC \\
\hline BOR-TU2-BOH & $\begin{array}{l}\text { Human bone } \\
\text { (long bone } \\
\text { shaft) }\end{array}$ & $\begin{array}{l}\text { TU2, level } 4 \\
(0.3-0.4 \mathrm{~m} \\
\text { depth })\end{array}$ & $\begin{array}{l}\text { No separable } \\
\text { collagen }\end{array}$ & N/A & N/A \\
\hline BOR-TU2-BOH1 & $\begin{array}{l}\text { Human bone } \\
\text { (femur shaft) }\end{array}$ & $\begin{array}{l}\text { TU2, level } 4 \\
(0.3-0.4 \mathrm{~m} \\
\text { depth })\end{array}$ & $\begin{array}{l}\text { No separable } \\
\text { collagen }\end{array}$ & N/A & N/A \\
\hline BOR-TU2-BOH2 & $\begin{array}{l}\text { Human bone (rib } \\
\text { shaft) }\end{array}$ & $\begin{array}{l}\text { TU2, level } 4 \\
(0.3-0.4 \mathrm{~m} \\
\text { depth })\end{array}$ & $\begin{array}{l}\text { No separable } \\
\text { collagen }\end{array}$ & N/A & N/A \\
\hline
\end{tabular}

All samples calibrated using OxCal v4.2 (Bronk Ramsey 2009); human bone calibrated as 50 per cent marine/50 per cent terrestrial; shell calibrated using Marine13 Curve (Reimer et al. 2013).

\section{Bioarchaeology}

Of the 1000 identified human remains recovered, about 200 were identifiable elements, including a small cache of isolates that had been collected from the surface by kayak tour guides and placed in a rock crevice to prevent looting. The remains are mineralised and highly fragmented, as evidenced by the recovery of numerous additional small fragments $(\mathrm{n}=987)$ that could not be identified beyond broader general categories (e.g. cranial, long bone and so on). With the exception of a single femur shaft located in level $2(0.1-0.2 \mathrm{~m})$ of TU2, the remains primarily consist of smaller fragments and disarticulated elements that (C) Antiquity Publications Ltd, 2017 
Table 2. Calibrated marine radiocarbon dates with various $\Delta \mathrm{R}$ for Palau.

\begin{tabular}{|c|c|c|c|c|c|c|c|}
\hline Laboratory number & Radiocarbon age & $\Delta \mathrm{R}-250 \pm 50^{1}$ & $\Delta \mathrm{R}-52 \pm 22^{2}$ & $\Delta \mathrm{R} 0$ & $\Delta \mathrm{R} 34 \pm 44^{3}$ & $\Delta \mathrm{R} 75 \pm 68^{4}$ & $\Delta \mathrm{R} 168 \pm 43^{5}$ \\
\hline D-AMS 016831 & $3450 \pm 30$ & $1850-1510 \mathrm{BC}$ & $1540-1320 \mathrm{BC}$ & $1460-1280 \mathrm{BC}$ & $1470-1190 \mathrm{BC}$ & $1470-1070 \mathrm{BC}$ & 1320-990 BC \\
\hline D-AMS 017432 & $3000 \pm 30$ & 1300-930 BC & $980-780 \mathrm{BC}$ & $900-760 \mathrm{BC}$ & $930-660 \mathrm{BC}$ & $920-510 \mathrm{BC}$ & $780-460$ BC \\
\hline D-AMS 017433 & $3370 \pm 30$ & $1720-1420 \mathrm{BC}$ & $1440-1230 \mathrm{BC}$ & $1380-1200 \mathrm{BC}$ & $1390-1080 \mathrm{BC}$ & 1390-970 BC & $1210-900 \mathrm{BC}$ \\
\hline D-AMS 017434 & $3960 \pm 30$ & $2500-2160 \mathrm{BC}$ & $2190-1950 \mathrm{BC}$ & $2110-1900 \mathrm{BC}$ & $2120-1800 \mathrm{BC}$ & $2110-1690 \mathrm{BC}$ & $1920-1630 \mathrm{BC}$ \\
\hline
\end{tabular}

${ }^{1}$ Fitzpatrick 2002; Masse et al. 2006.

${ }^{2}$ Petchey \& Clark 2010.

${ }^{3}$ Yoneda et al. 2007.

${ }^{4}$ Petchey \& Clark 2010.

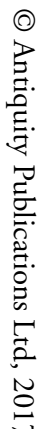

${ }^{5}$ Yoneda et al. 2007.

\section{Research}


were recovered from each level of the test unit. Similar to the faunal assemblage, the bulk of the remains were found in the upper levels, suggesting that individuals may have been originally placed on the surface of the cave floor or in shallow subsurface graves. This is also consistent with early mortuary contexts at other burial caves and rockshelters in the Rock Islands, where both subsurface burial in beach sand and placement on cave floors were common practices (Fitzpatrick \& Nelson 2008).

As the assemblage consisted solely of disarticulated elements, no discrete individuals or articulated burials could be identified. A rough estimate of MNI based on nonrepetitive elements, however, suggests that at least six individuals are represented, including three adults and three juveniles, ranging in age from infancy to adulthood. Although no elements that can be used to determine sex accurately were recovered, the presence of individuals across such a broad age range suggests that there were no age- or sex-related interment restrictions in place at Ucheliungs Cave. This is also similar to the demographic composition of the Orrak and Koror Quarry sites, which contained assemblages representing both sexes and a wide age range (Rieth \& Liston 2001; Stone et al. 2014; Nelson et al. 2015). Pathological conditions were identified in 18 elements (1.5 per cent of total skeletal assemblage), and are limited to degenerative changes, such as pitting and marginal growth affecting articular joint surfaces. These can probably be attributed to age or activity-related factors. No traumatic injuries were identified, with the exception of a possible healed fracture on a proximal hand phalanx. A single instance of pedal symphalangism (the fusion of the intermediate and distal foot phalanges) was the only skeletal anomaly identified. There is no pathognomonic evidence for dwarfism, nor are there any indications of small body size from the elements recovered. Although this is an extremely limited sample, the pattern observed at Ucheliungs Cave appears similar to that of both Orrak and Koror Quarry, where trauma and pathology are only minimally present (Rieth \& Liston 2001; Nelson \& Fitzpatrick 2006; Nelson et al. 2015).

Isolated teeth $(\mathrm{n}=29)$ were also recovered, along with a single mandibular fragment containing three teeth from the cache collected by the tour guides. Dental health is comparable to other prehistoric Palauan assemblages, and includes light occlusal wear, a lack of carious lesions and slight calculus formation, primarily confined to the cementoenamel junction. As seen at Chelechol ra Orrak, a number of the teeth from Ucheliungs Cave were also stained from the habitual chewing of betel nut (Areca catechu), a common practice throughout Palau (Fitzpatrick et al. 2003a). Dental studies have suggested that chewing betel nut creates cariostatic conditions, possibly as a result of tannins in the drupe that possess antimicrobial properties, or increases saliva production. This may explain the noticeable absence of carious lesions in this assemblage and others from Palau (Howden 1984; de Miranda et al. 1996; Trivedy et al. 2002). Unlike at Orrak, where all but two burials exhibit staining, betel staining occurs in less than half $(n=12)$ of the teeth recovered—although this may be a reflection of the small sample size at Ucheliungs Cave. Deciduous teeth also exhibited a dark staining, but this appears to be taphonomic, as betel staining has not been observed in deciduous teeth from the Chelechol ra Orrak assemblage (such staining is markedly different in colour). Furthermore, this cultural behaviour was historically usually restricted to adults.

(C) Antiquity Publications Ltd, 2017 


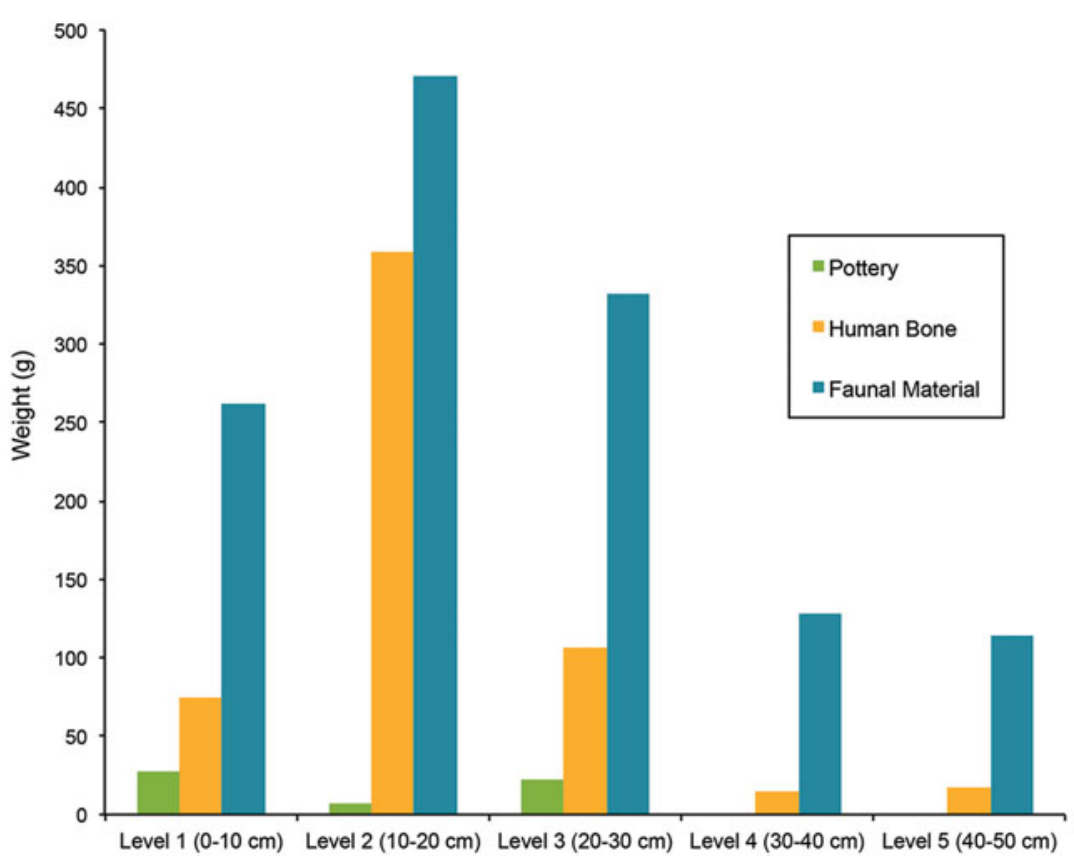

Figure 4. Relative contributions of faunal remains, human remains and ceramics to assemblage.

\section{Archaeozoology}

Fauna recovered from TU2 consist almost exclusively of marine molluscs (88 per cent of the total faunal weight), and were present in each level of TU2, with the bulk of the assemblage belonging to the upper three levels (Figure 4). The majority of the shell and all of the faunal bone are bleached and mineralised, exhibiting a similar level of preservation to the human bone. This complicated identification of many taxa; as such, few are identified below the family level.

Bivalves and gastropods are represented relatively equally, with a total of 55 taxa. While no single taxon dominated the assemblage, Arcidae sp., Conus sp., Nerita sp. and Videna sp. were all found in relatively high quantities (Table S1). Additionally, three species of land snail, including Videna sp., were found throughout all levels and represent a substantial portion of the gastropod assemblage ( 4 per cent of the total gastropod weight, and 1.4 per cent of the overall shell weight; 49 per cent of the total gastropod MNI, 31.5 per cent of the total shell MNI). The shellfish assemblage at Ucheliungs Cave appears to be similar to that observed at other sites in the Rock Islands, including stone money (rai) quarries and village sites, where taxa from intertidal and shallow reef environments are common. These include taxa from the Arcidae, Conidae, and Cypraeidae families (Carucci 1992; Fitzpatrick 2003b).

A small amount of vertebrate material was also identified, including two shark teeth, a single centrum of a fish vertebra and a bird coracoid. Also present are a species of barnacle (Cirripedia sp.) found throughout all levels, small quantities of sea urchin (Echinoidea sp.), chiton and crab (Brachyura sp.). The latter is the most abundant taxon (apart from 


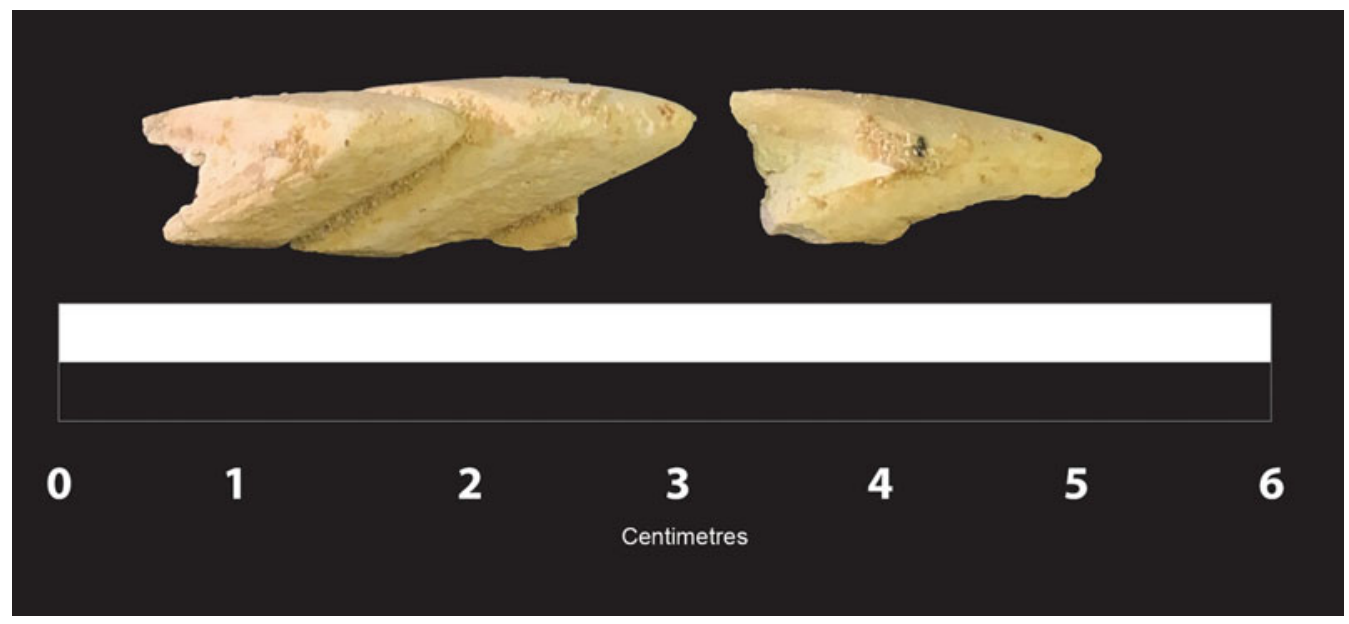

Figure 5. Carved bone artefact from the south-eastern wall of test unit 2.

marine shell), comprising 9 per cent of the overall weight. Together, the combined faunal assemblage from TU2 weighs $1530.52 \mathrm{~g}$ and represents 66 taxa, including many that are endemic to the shallow reef environments in the immediate vicinity of Ucheliungs Cave. It therefore appears that although terrestrial resources may have been scarce, the abundance of marine resources in no way suggests that a reduced resource base-one of the contributing factors to insular dwarfing-was present at Ucheliungs Cave. It also supports the use of a mixed marine diet in the calibration of radiocarbon dates on human bone.

\section{Artefacts}

A total of 30 pottery sherds weighing $759.73 \mathrm{~g}$ were recovered from TU2 and the surface of the north-west cavern of the cave (Table S2). Sherds from TU2 were recovered from the first three levels, and all are small, undecorated body fragments. Multiple sherds appeared to be weathered and lacking interior or exterior surfaces, which may be due to taphonomic processes that are known to contribute to post-depositional wear on sherd surfaces (Clark 2005). Body sherd thickness ranged from $3.96-10.18 \mathrm{~mm}$, but the small sample size is not sufficient to address possible changes in manufacturing technology across levels. Preliminary temper analysis indicates that sherds were produced with volcanic sand as temper, which is significant, given that most Palauan pottery was made with grog temper (Osborne 1979; Fitzpatrick et al. 2003b). The total absence of grog temper, coupled with the AMS dates, supports earlier findings that volcanic-sand-tempered pottery is associated with the earliest occupation of the Rock Islands (Fitzpatrick et al. 2003b; Clark 2005).

The only other artefact was a single piece of carved bone (of unknown species) recovered from the south-eastern corner of TU2, at approximately $0.1 \mathrm{~m}$. The artefact is of particular interest because it is decorated with linear and triangular carving, and may be a fragment of a harpoon tip used for fishing (Figure 5). The fragment is currently undergoing analysis via archaeozoology by mass spectrometry (ZooMS). This process relies on the specieslevel variability in type I collagen (a dominant bone protein) to identify archaeological bone taxonomically through non-destructive collagen fingerprinting. ZooMS is particularly (C) Antiquity Publications Ltd, 2017 
useful for distinguishing between taxa that are morphologically similar, or non-diagnostic bone fragments, such as this artefact (Buckley et al. 2009, 2014; Buckley \& Collins 2011). Results will be reported separately in the future.

\section{Discussion}

The results from the analysis of recently excavated archaeological and skeletal material recovered from the Ucheliungs site are significant, as they present a drastically different picture of prehistoric use compared to previous research, and contradict Berger et al.'s (2008) claim that the site was used exclusively for mortuary practice by small-bodied humans. Our new findings indicate that cultural activities at Ucheliungs Cave were actually more varied and occurred across a longer period of time than previously reported. Faunal remains, artefacts and dates on marine shell suggest that use of the site occurred earlier than previously reported. Berger et al. argued that insular dwarfing occurs in tropical environments due to a combination of factors, including "relative genetic isolation, a reduced resource base, hot and humid climates, hilly topography, thick undergrowth of vegetation, and (in certain island contexts) an absence of terrestrial predators" (Berger et al. 2008: 1). The presence of a diverse and abundant marine taxa assemblage and artefacts that were transported to the site (which are also commonly found on many other Rock Islands), however, suggest that genetic isolation and a reduced resource base were not factors affecting the inhabitants of Ucheliungs Cave. Furthermore, the overall assemblage recovered from TU2 is similar to what has been observed at other prehistoric sites in the Rock Islands, and does not indicate a population that would have been culturally or biologically distinct or isolated from other early Palauan groups.

Although the sample size is small, it appears that broad demographic and pathological patterns from other prehistoric Palauan skeletal assemblages are comparable to those observed at Ucheliungs Cave. Given the early radiocarbon dates from TU2 that are associated with human remains, additional analysis of the existing skeletal assemblage and continued work at Ucheliungs Cave has great potential to provide information related to early Palauan health. This research, and that planned for the future at Ucheliungs Cave, will also contribute to a more comprehensive and much-needed collection of skeletal samples from the Rock Islands when combined with the substantial information known from burials at Chelechol ra Orrak (Nelson \& Fitzpatrick 2006; Nelson et al. 2015).

\section{Conclusions}

Berger et al. (2008: 3) argued that the Ucheliungs site contained the remains of smaller humans for which "the most parsimonious, and most reasonable, interpretation of the human fossil assemblage [...] is that they derive from a small-bodied population of $H$. sapiens (representing either rapid insular dwarfism or a small-bodied colonizing population)". Fitzpatrick et al. (2008) demonstrated the many fallacies inherent in Berger et al.'s (2008) interpretation, in particular in discounting the presence of Palau's rich marine environment, which would have provided excellent resources for prehistoric populations to exploit (and as such, the inverse of conditions needed to induce insular dwarfism or a biological tendency for smaller bodies). Archaeological research at numerous sites 
throughout the archipelago also clearly demonstrates that interaction between islands over time was frequent and intense, as evidenced by the transportation of pottery and other artefacts to the limestone Rock Islands, which lacked clay or tool-quality stone. Thus, the notion of a population residing at Ucheliungs Cave in isolation for hundreds or thousands of years is unthinkable.

The material we recovered in TU2 - a unit the same size adjoining the one excavated by Berger et al. (2008) - includes the very evidence (marine taxa, non-local artefacts) that was used to support the notion of isolation for the cave's inhabitants, a key component in their interpretation that small-bodied individuals were present here. That so many indicators of human use or occupation were either ignored, dismissed or unidentified also calls into question the methods used by Berger et al. (2008), and demonstrates a failure to recover and analyse various site constituents that are commonly found in Palau's Rock Islands and other sites in the Pacific. Continued work at the Chelechol ra Orrak cemetery is providing new and important data on Palau's prehistoric inhabitants from both archaeological and biological perspectives. The Ucheliungs site, which to date has yielded only very fragmented and widely dispersed skeletal remains, is significant for its potentially early dates and associated cave activities, but not for its contribution to human evolutionary processes that involved isolated populations or small-bodied individuals.

\section{Acknowledgements}

This research was supported by a Wenner Gren Foundation Dissertation Fieldwork grant (9104), the Edna English Foundation for Archaeological Research from the University of Oregon Museum of Natural and Cultural History, a Global Oregon Graduate Research Grant, the Center for Asian and Pacific Studies at the University of Oregon, and the 2015 study abroad programme led by Fitzpatrick through Global Education Oregon. Special thanks go to the Palau Bureau of Cultural and Historic Preservation; to the undergraduate students who participated in the 2015 field project; to Mike Buckley and Virginia Harvey for conducting ZooMS; to Connor Thorud, who assisted with analysis of the faunal material, and to Patrick Kirch and an anonymous reviewer for providing comments that improved the manuscript.

\section{Supplementary material}

To view supplementary material for this article, please visit https://doi.org/10.15184/aqy. 2017.184

\section{References}

Athens, J.S. \& J. WARD. 1999. Archaeological data recovery for the compact road, Babeldaob Island, Republic of Palau. Historic preservation investigations phase II. Volume IV: the Holocene paleoenvironment of Palau. Honolulu (HI): International Archaeological Research Institute.

Berger, L.R., S.E. Churchill, B. De Klerk \& R.L. Quinn. 2008. Small-bodied humans from Palau, Micronesia. PLoS ONE 3(3): e1780. https://doi.org/10.1371/journal.pone.0001780

Bronk Ramsey, C. 2009. Bayesian analysis of radiocarbon dates. Radiocarbon 51: 337-60. https://doi.org/10.1017/S0033822200033865
Buckley, M. \& M.J. Collins. 2011. Collagen survival and its use for species identification in Holocene-Lower Pleistocene bone fragments from British archaeological and paleontological sites. Antiqua 1(1): 1-7. https://doi.org/10.4081/antiqua.2011.e1

Buckley, M., M. Collins, J. Thomas-Oates $\&$ J.C. Wilson. 2009. Species identification by analysis of bone collagen using matrix-assisted laser desorption/ionization time-of-flight mass spectrometry. Rapid Communications in Mass Spectrometry 23: 3843-54. https://doi.org/10.1002/rcm.4316

(C) Antiquity Publications Ltd, 2017 


\section{Disproving claims for small-bodied humans in the Palauan archipelago}

Buckley, M., S. Fraser, J. Herman, N.D. Melton, J. Mulville \& A. PÁlsdóttir. 2014. Species identification of archaeological marine mammals using collagen fingerprinting. Journal of Archaeological Science 41: 631-41. https://doi.org/10.1016/j.jas.2013.08.021

Buikstra, J. \& D. Ubelaker. 1994. Standards for data collection from human skeletal remains (Arkansas Archaeological Survey Research Series 44). Fayetteville: Arkansas Archaeological Survey.

CArucci, J. 1992. Cultural and natural patterning in prehistoric marine foodshell from Palau, Micronesia. Unpublished PhD dissertation, Southern Illinois University at Carbondale.

Clark, G. 2004. Radiocarbon dates from the Ulong site in Palau and implications for western Micronesian prehistory. Archaeology in Oceania 39: 26-33. https://doi.org/10.1002/j.18344453.2004.tb00554.x

- 2005. A 3000-year culture sequence from Palau, Micronesia. Asian Perspectives 44: 349-80.

Clark, G. \& C. Reepmeyer. 2012. Last millennium climate change in the occupation and abandonment of Palau's Rock Islands. Archaeology in Oceania 47: 29-38. https://doi.org/10.1002/j.18344453.2012.tb00112.x

Clark, G., A. Anderson \& D. Wright. 2006. Human colonization of the Palau Islands, western Micronesia. Journal of Island and Coastal Archaeology 1: 215-32. https://doi.org/10.1080/15564890600831705

Corwin, C.G., C.L. Rogers \& P.O. Elmquist. 1956. Military geology of Palau Islands, Caroline Islands. Tokyo: Intelligence Division, Office of the Engineer, Headquarters U.S. Army Far East.

de Miranda, C., C. van Wyk, P. van der Biji $\&$ N. BAsson. 1996. The effect of areca nut on salivary and selected oral microorganisms. International Dental Journal 46: 350-56.

FitzPATRICK, S.M. 2002. AMS dating of human bone from Palau: new evidence for a pre-2000 B.P. settlement. Radiocarbon 44: 217-22. https://doi.org/10.1017/S003382220006481X

- 2003a. Early human burials in the western Pacific: evidence for $c$. 3000-year-old occupation on Palau. Antiquity 77: 719-31. https://doi.org/10.1017/S0003598X00061664

- 2003b. Shellfish assemblages from two limestone quarries in the Palau Islands. Journal of Ethnobiology 23: 101-23.

Fitzpatrick, S.M. \& G.C. Nelson. 2008. From limestone caves to concrete graves: 3000 years of mortuary practice in the Palauan archipelago, Micronesia. International Journal of Osteoarchaeology 18: 439-57. https://doi.org/10.1002/oa.951
Fitzpatrick, S.M., G.C. Nelson \& R. Reeves. 2003a. The prehistoric chewing of betel nut (Areca catechu) in western Micronesia. People and Culture in Oceania 19: 55-65.

Fitzpatrick, S.M., W.D. Dickinson \& G. Clark. 2003b. Ceramic petrography and cultural interaction in Palau, Micronesia. Journal of Archaeological Science 30: 1175-84. https://doi.org/10.1016/S0305-4403(03)00014-1

Fitzpatrick, S.M., G.C. Nelson \& G. Clark. 2008. Small scattered fragments do not a dwarf make: biological and archaeological data indicate that prehistoric inhabitants of Palau were normal sized. PLoS ONE 3(8): e3105.

Howden, G. 1984. The cariostatic effects of betel chewing. Papua and New Guinea Medical Journal 27: 123-31.

Masse, W.B., J. Liston, J. Carucci \& J.S. Athens. 2006. Evaluating the effects of climate change on environment, resource depletion, and culture in the Palau Islands between AD 1200 and 1600. Quaternary International 151: 106-32. https://doi.org/10.1016/j.quaint.2006.01.017

Nelson, G.C. \& S.M. Fitzpatrick. 2006. Preliminary investigations of the Chelechol ra Orrak Cemetery, Republic of Palau: I, skeletal biology and paleopathology. Anthropological Science 114: 1-12. https://doi.org/10.1537/ase.040710

Nelson, G.C., J.H. Stone \& S.M. Fitzpatrick. 2015. Adapting to Palau, in M. Oxenham \& H. Buckley (ed.) The Routledge handbook of bioarchaeology in Southeast Asia and the Pacific Islands: 502-26. Abingdon: Routledge.

Ono, R. \& G. Clark. 2012. A 2500-year record of marine resource use on Ulong Island, Republic of Palau. International Journal of Osteoarchaeology 22: 637-54. https://doi.org/10.1002/oa.1226

Osborne, D. 1979. Archaeological test excavations, Palau Islands, 1968-1969 (Micronesica supplement 1). Mangilao: University of Guam.

Petchey, F. \& G. Clark. 2010. A marine reservoir correction value $(\Delta R)$ for the Palauan archipelago: environmental and oceanographic considerations. Journal of Island and Coastal Archaeology 5: 236-52. https://doi.org/10.1080/15564890903155935

Reimer, P.J., E. Bard, A. Bayliss, J.W. Beck, P.G. Blackwell, C. Bronk Ramsey, C.E. Buck, H. Cheng, R.L. Edwards, M. Friedrich, P.M. Grootes, T.P. Guilderson, H. Haflidason, I. Hajdas, C. Hatté, T.J. Heaton, D.L. Hoffmann, A.G. Hogg, K.A. Hughen, K.F. Kaiser, B. Kromer, S.W. Manning, M. Niu, R.W. Reimer, D.A. Richards, E.M. Scott, J.R. Southon, R.A. Staff, C.S.M. Turney $\&$ J. van Der Plicht. 2013. IntCal13 and Marine13 radiocarbon age calibration curves $0-50,000$ years cal BP. Radiocarbon 55: 1869-87. https://doi.org/10.2458/azu_js_rc.55.16947

(C) Antiquity Publications Ltd, 2017 
Reitz, E.J. \& E.S. Wing. 2008. Zooarchaeology. Cambridge: Cambridge University Press. https://doi.org/10.1017/CBO9780511841354

Rieth, T.M. \& J. Liston. 2001. Archaeological data recovery at Ngermereues Ridge, Ngesaol, Koror, Republic of Palau. Honolulu (HI): International Archaeological Research Institute, Inc.

Rick, T.C., R.L. Vellanoweth \& J.E. Erlandson. 2005. Radiocarbon dating and the 'old shell' problem: direct dating of artifacts and cultural chronologies in coastal and other aquatic regions. Journal of Archaeological Science 32: 1641-48. https://doi.org/10.1016/j.jas.2005.05.005

Scheuer, L., S. Black \& M. Schaefer. 2000. Juvenile osteology. San Diego (CA): Academic.
Stone, J.H., G.C. Nelson \& S.M. Fitzpatrick. 2014. Demography at the Chelechol ra Orrak cemetery, Republic of Palau. Poster presented at the Society for American Archaeology Annual Meeting, Austin, TX, 23-27 April 2014.

Trivedy, C.R., G. Craig \& S. Warnakulasuriya. 2002. The oral health consequences of chewing areca nut. Addiction Biology 7: 115-25. https://doi.org/10.1016/j.nimb.2007.01.184

Yoneda, M., H. Uno, Y. Shibata, R. Suzuki, Y. Кumamoto, K. Yoshida, T. Sasaki, A. SuzuKi \& H. KaWAHATA. 2007. Radiocarbon marine reservoir ages in the western Pacific estimated by pre-bomb molluscan shells. Nuclear Instruments and Methods in Physics Research Section B: Beam Interactions with Materials and Atoms 259(1): 432-37. https://doi.org/10.1016/j.nimb. 2007.01.184

Received: 7 November 2016; Accepted: 7 February 2017; Revised: 15 February 2017

(C) Antiquity Publications Ltd, 2017 